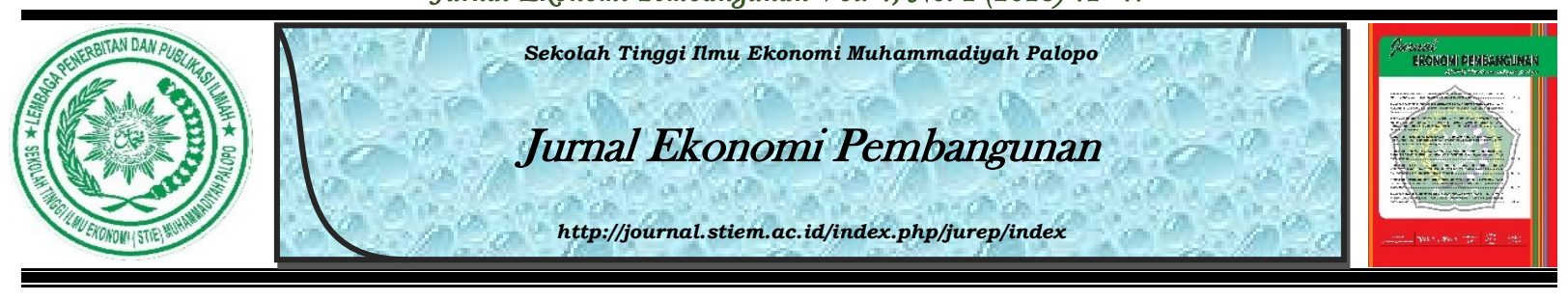

\title{
Analisis Penerapan Metode Gross $U p$ sebagai Upaya Perencanaan Pajak pada PT Pelni (Persero) Cabang Parepare
}

Darmawan $^{1}$, Yasri Tarawiru ${ }^{2}$

${ }^{1,2}$ Universitas Muhammadiyah Parepare

\begin{tabular}{l} 
INFO NASKAH \\
\hline Diserahkan \\
23 November 2018 \\
Diterima \\
23 November 2018 \\
Diterima dan disetujui \\
29 Desember 2018 \\
\hline
\end{tabular}

\section{Kata Kunci:}

Metode gross up

Pajak penghasilan pasal 21

Pajak penghasilan badan

\begin{abstract}
ABSTRAK
Penelitian ini bertujuan untuk mengetahui besarnya pajak yang ditanggung oleh perusahaan sebelum dan sesudah penerapan metode gross up dan untuk mengetahui beban pajak yang dapat dikurangi pada perusahaan sebagai hasil penerapan metode gross up. Penelitian ini menggunakan pendekatan kuantitatif. Metode pengumpulan data yang digunakan dalam penelitian ini adalah observasi, wawancara, dan dokumentasi, dengan menggunakan dua metode pengumpulan data yaitu studi pustaka dan studi lapangan. Hasil penelitian menunjukkan bahwa jumlah beban pajak perusahaan setelah penerapan metode gross up yaitu Rp4.769.242 dimana lebih efisien jika dibandingkan dengan sebelum perencanaan pajak adalah Rp7.370.326.
\end{abstract}

\section{Pendahuluan}

Pajak merupakan sumber utama penerimaan negara. Tanpa pajak, kegiatan negara sulit untuk dapat dilaksanakan. Sebagian besar dana yang digunakan untuk membiayai pengeluaran sehubungan dengan kegiatan penyelenggaraan negara berasal dari pajak. Gross-up method adalah metode di mana perusahaan memberikan tunjangan pajak sama besar dengan PPh Pasal 21 yang dipotong atas gaji karyawan. Metode ini menimbulkan beban bagi perusahaan yang tidak menimbulkan koreksi positif dalam rekonsiliasi fiskal (deductable expenses) sehingga pajak terutang perusahaan lebih efisien. Bagi karyawan menambah penghasilan bruto, take home pay sama dengan net method, dan kewajiban pajak terpenuhi.

Berdasarkan penjelasan di atas dapat disimpulkan bahwa metode gross up adalah metode yang wajib untuk diterapkan dalam perusahaan sebagai upaya perencanaan pajak dimana selain memberikan dampak langsung pada pajak terutang perusahaan lebih efisien, sekaligus menambah penghasilan bruto karyawan yang diharapkan dapat mendorong motifasi kerja 
sehingga meningkatkan produktifitas perusahaan.

PT PELNI adalah perusahaan yang bergerak di bidang jasa pelayaran nasional yang memiliki cabang di Parepare. Pendapatan serta aset yang dimiliki oleh perusahaan menjadikan perusahaan termasuk sebagai subjek pajak berdasarkan undang-undang pajak penghasilan pasal 2 UU No $.36 / 2008$ sebagai berikut yang terdiri dari orang pribadi, badan, dan bentuk usaha tetap. Dilanjutkan lagi pada pasal berikutnya tentang pengertian objek pajak menurut pasal 4 ayat (1) UU No. 36/2008 "yang menjadi objek pajak adalah penghasilan, yaitu setiap tambahan kemampuan ekonomis yang diterima atau diperoleh Wajib pajak, baik yang berasal dari Indonesia maupun dari luar Indonesia, yang dapat dipakai untuk konsumsi atau untuk menambah kekayaan wajib pajak yang bersangkutan.

Berdasarkan pertimbangan inilah yang menjadi acuan penulis dalam memilih PT PELNI untuk dilakukan penelitian lebih seksama mengenai penerapan metode gross up dalam upaya perencanaan pajak pada perusahaan tersebut. Penulis mengharapkan bahwa perusahaan melakukan perencanaan pajak dengan baik dan benar tanpa harus melanggar peraturan undang-undang pajak yang berlaku.

Penelitian ini bertujuan untuk mengetahui besarnya pajak yang ditanggung oleh perusahaan sebelum dan sesudah penerapan metode gross up dan untuk mengetahui beban pajak yang dapat dikurangi pada perusahaan sebagai hasil penerapan metode gross up. Hasil penelitian ini diharapkan menjadi bahan kajian ilmiah pada bidang ilmu ekonomi akuntansi, khususnya pengkajian di bidang perpajakan dan menjadi sumbang saran pada semua pihak, khususnya pada PT PELNI (PERSERO) Cabang Parepare dan peneliti-peneliti selanjutnya.

\section{Kajian Pustaka}

Pembangunan nasional adalah kegiatan yang berlangsung terus-menerus dan berkesinambungan yang bertujuan meningkatkan kesejahteraan rakyat baik materil maupun spiritual. Untuk dapat merealisasikan tujuan tersebut perlu perlu banyak memperhatikan masalah pembiayaan-pembiayaan pembangunan (Waluyo, 2009). Menurut Gunarso (2010) gross-up method adalah metode di mana perusahaan memberikan tunjangan pajak sama besar dengan PPh Pasal 21 yang dipotong atas gaji karyawan. Metode ini menimbulkan beban bagi perusahaan yang tidak menimbulkan koreksi positif dalam rekonsiliasi fiskal (deductable expenses) sehingga pajak terutang perusahaan lebih efisien. Bagi karyawan menambah 
penghasilan bruto dan kewajiban pajak terpenuhi.

Berikut ini adalah rumus untuk menentukan besaran tunjangan pajak yang di gross up menurut Chairil Anwar Pohan (2011) seperti terlihat pada tabel dibawah ini:

Tabel 1. Metode Gross Up

\begin{tabular}{|l|c|}
\hline \multicolumn{1}{|c|}{ PKP/tahun } & Rumus menghitung tunjangan PPh 21 \\
\hline s/d 50.000 .000 & $\frac{\text { PKP X 5\% }}{0,9525}$ \\
\hline $50.000 .000 \mathrm{~s} / \mathrm{d} 250.000 .000$ & $\frac{(\text { PKP X 15\%) - 5 Juta }}{0,85}$ \\
\hline $250.000 .000 \mathrm{~s} / \mathrm{d} 500.000 .000$ & $\frac{(\text { PKP X 25\%) - 30 Juta }}{0,75}$ \\
\hline $500.000 .000 \mathrm{~s} / \mathrm{d} \ldots$. & $\underline{\text { PKP X 30 \%) - 55 Juta }}$ \\
& 0,70 \\
\hline
\end{tabular}

Menurut Zain (2005), perencanaan pajak adalah tindakan yang terkait dengan konsekuensi potensi pajaknya, yang ditekankan kepada pengendalian setiap transaksi yang ada konsekuensi pajaknya. Tujuannya adalah bagaimana pengendalian tersebut dapat mengefisienkan jumlah pajak yang akan diberikan ke pemerintah melalui apa yang disebut sebagai penghindaran pajak (tax avoidance) dan penyelunndupan pajak (tax evasion) yang merupakan tindak pidana fiskal.

Berdasarkan pengertian perencanaan pajak diatas, dapat disimpulkan bahwa perencanaan pajak melalui penghindaran pajak merupakan satu-satunya cara legal yang dapat ditempuh oleh wajib pajak dalam rangka mengefisienkan pembayaran pajaknya. Suatu perencanaan pajak yang efektif tidak tergantung kepada seseorang ahli pajak yang profesional, melainkan akan sangat tergantung kepada kesadaran dan keterlibatan para pengambil keputusan akan adanya konsekuensi pajak yang melekat pada setiap aktivitas perusahaaan.

\section{Metode Penelitian}

\subsection{Desain Penelitian}

Desain penelitian yang digunakan dalam penulisan ini adalah metode deskriptif anallisis yaitu suatu penelitian yang dilakukan dengan cara mengumpulkan data sesuai dengan keadaan 
yang sebenarnya, kemudian dianalisis dan menginterpretasikan data dan fakta yang diperoleh untuk memberikan penilaian dan menarik kesimpulan yang diperlukan secara umum dengan pendekatan simulasi.

Biaya deductible itu sudah jelas, secara eksplisit tertuang dalam Pasal $4 \mathrm{UU} \mathrm{PPh}$, sesuai dengan makna prinsip taxability-deductibility. Artinya apabila penghasilan (dari tunjangan pajak) karyawan tersebut sudah dipajaki dan disetorkan ke Kas Negara serta sudah dilaporkan dalam SPT PPh Pasal 21, maka bagi pemberi kerja atas pengeluaran (biaya tunjangan pajak) tersebut dapat dibiayakan menjadi pengurang penghasilan dalam laporan keuangan fiskal atau SPT PPh Badan. Tentu dengan catatan, transaksi tersebut didukung dengan adanya penjurnalan biaya tunjangan pajak didalam pembukuan wajib pajak serta juga tercantum dalam slip gaji karyawan.

Penelitian ini menggunakan tiga metode yaitu observasi, wawancara, dan menghitung perencaan pajak dengan menggunakan undang-undang perpajakan yang berlaku dan membandingkannya dengan perencanaan pajak yang diterapkan perusahaan. Data-data yang dikumpulkan yaitu SPT Masa Pajak Penghasilan (PPh) Pasal 21 tahun 2015 (12 bulan) dan daftar gaji pegawai tetap PT Poleko tahun 2015.

\subsection{Jenis dan Sumber Data}

Jenis data dalam penelitian ini adalah data kualitatif dan kuantitatif. Data kualitatif, yaitu data yang diperoleh dari perusahaan berupa informasi baik secara lisan maupun tulisan. Data kuantitatif yaitu data yang diperoleh dari perusahaan berupa data dalam bentuk angka-angka. Adapun sumber data dalam penelitian ini terdiri dari sumber data primer dan sumber data sekunder. Data primer, merupakan sumber data yang diperoleh langsung dari sumber asli (tidak melalui media perantara). Data primer dapat berupa opini subjek (orang) secara individual atau kelompok, hasil observasi terhadap suatu benda (fisik), kejadian atau kegiatan, dan hasil pengujian. Metode yang digunakan untuk mendapatkan data primer yaitu metode survei dan metode observasi. Data sekunder, merupakan sumber data penelitian yang diperoleh peneliti secara tidak langsung melalui media perantara (diperoleh dan dicatat oleh pihak lain). Data sekunder umumnya berupa bukti, catatan atau laporan historis yang telah tersusun dalam arsip (data dokumenter) yang dipublikasikan dan yang tidak dipublikasikan. 


\subsection{Teknik Pengumpulan Data}

Teknik pengumpulan data dalam penelitian ini adalah observasi, yaitu dengan mengadakan pengamatan langsung atas objek yang diteliti dengan memperoleh gambaran mengenai permasalahan yang diahapi oleh perusahaa. Selain itu teknik dokumentasi juga digunakan dalam penelitian ini. Dokumentasi, yaitu dengan mengumpulkan dan menganalisa dokumen-dokumen perusahaan yang diperlukan.

\subsection{Pengukuran Variabel}

Untuk memberikan persamaan persepsi kepada pembaca, maka penulis menggunakan definisi operasional, yaitu:

a. Metode Gross Up

Metode gross up adalah metode di mana perusahaan memberikan tunjangan pajak sama besar dengan PPh Pasal 21 yang dipotong atas gaji karyawannya.

b. Pajak Penghasilan Pasal 21

Pajak penghasilan pasal 21 adalah pajak atas penghasilan berupa gaji, upah, honorarium, tunjangan, dan pembayaran lain dengan nama dan dalam bentuk apapun sehubungan dengan pekerjaan atau jabatan, jasa, dan kegiatanyang dilakukan oleh orang pribadi Subjek Pajak dalam negeri, sebagaimana dimaksud dalam Pasal 21 Undang-Undang Pajak Penghasilan.

c. Perencanaan Pajak

Perencanaan pajak adalah tindakan yang terkait dengan konsekuensi potensi pajaknya, yang ditekankan kepada pengendalian setiap transaksi yang ada konsekuensi pajaknya.

\subsection{Teknik Analisis Data}

Teknik analisis data yang digunakan dalam penelitian ini mengacu pada formula perhitungan metode gross up seperti yang ada dalam tabel 1 di atas. 


\section{Hasil dan Pembahasan Penelitian}

Pada perhitungan pajak PPh pasal 21 sebelum dan sesudah penerapan metode gross up diatas, terlihat perbedaan pendapatan yang diterima. Penerapan metode gross up dimana tunjangan pajak yang diberikan sama besar dengan jumlah pajak yang harus dibayarkan oleh karyawan yang menyebabkan jumlah pajak yang harus dipotong adalah nihil. Pemberian tunjangan pajak di-gross up ini dapat dibiayakan kerena tunjangan ini masuk dalam bagian penghasilan yang diterima karyawan. Hasil ini menunjukkan bahwa gross up dapat digunakan sebagai perhitungan perpajakan sesuai peraturan yang berlaku.

Pemberian tunjangan pajak yang di-gross up merupakan bagian dari penghasilan yang diterima karyawan bukan merupakan kenikmatan yaitu sebesar Rp2.601.084. Artinya apabila penghasilan (dari tunjangan pajak) karyawan tersebut sudah dipajaki dan disetorkan ke Kas Negara serta sudah dilaporkan dalam SPT PPh Pasal 21, maka bagi pemberi kerja atas pengeluaran (biaya tunjangan pajak) tersebut dapat dibiayakan menjadi pengurang penghasilan dalam laporan keuangan fiskal atau SPT PPh Badan. Tentu dengan catatan, transaksi tersebut didukung dengan adanya penjurnalan biaya tunjangan pajak didalam pembukuan wajib pajak serta juga tercantum dalam slip gaji karyawan. Hasil ini menunjukkan bahwa besarnya beban pajak yang dapat dikurangi pada perusahaan setelah penerapan metode gross up.

\section{Simpulan dan Saran}

Perbandingan perhitungan Pajak Penghasilan (PPh) Pasal 21 dengan metode gross up menunjukkan bahwa metode gross up atau pemberian tunjangan pajak pada karyawan yang sama besarnya dengan jumlah pajak yang terutang menghasilkan efesiensi terhadap Pajak Penghasilan (PPh) Badan sebesar Rp2.601.084. Implementasi perencanaan pajak melalui pemberian tunjangan di gross up PT PELNI (PERSERO) Cabang Parepare dapat melakukan penghematan yang lebih maksimal dan disisi lain hal ini dapat memberikan kesan baik untuk meningkatkan kesejahteraan dan kepedulian terhadap karyawan.

Saran untuk PT PELNI (PERSERO) Cabang Parepare sebaiknya lebih mengkaji secara mendalam ketentuan undang-undang perpajakan untuk mendapatkan lebih banyak celah dalam ketentuan tersebut sehingga beban pajak dapat ditekan secara maksimal. Selaijn itu, sebaiknya menggunakan alternatif perhitungan pajak dengan cara memberi tunjangan yang di 
gross up karena selain menghemat pajak juga meningkatkan kesejahteraan karyawan.

\section{Daftar Pustaka}

Ikatan Akuntan Indonesia. 2009. Standar Akuntansi Keuangan. Jakarta: Salemba Empat.

Ikatan Akuntansi Indonesia. 2002. Standar Akuntansi Keuangan. Edisi Revisi. Jakarta: PT Renika Cipta

Ilyas, W.B. 2013. Praktikum Perpajakan. Edisi 2. Jakarta: In Media.

Mardiasmo. 2001. Perpajakan. Edisi Revisi. Yogyakarta: Penerbit Andi.

Masyahrul, T. 2006. Pengantar Perpajakan. Jakarta: PT Grasindo.

Omposunggu, A.P. 2011. Cara Legal Siasati Pajak. Jakarta: Puspa Swara.

Pohan, C.A. 2011. Optimizing Corporate Tax Management: Kajian Perpajakan dan Tax Planning-Nya Terkini. Jakarta: Bumi Aksara.

Republik Indonesia. 2008. Peraturan Menteri Keuangan Nomor 162/PMK.011/2012 tentang Penyesuaian Besarnya Penghasilan Tidak Kena Pajak. Jakarta.

Republik Indonesia. 2008. Peraturan Menteri Keuangan Nomor 250/PMK.03/2008 tentang Besarnya Biaya Jabatan atau Biaya Pensiun yang Dapat Dikurangkan. Jakarta.

Republik Indonesia. 2008. Peraturan Pajak Penghasilan Pasal 2 tentang Subjek Pajak. Bandung: Fokus Media.

Republik Indonesia. 2008. Peraturan Pajak Penghasilan Pasal 4 Nomor 36/2008 tentang Objek Pajak. Bandung: Fokus Media.

Suandy, E. 2008. Perencanaan Pajak. Edisi Keempat. Jakarta: Salemba Empat.

Thomas, S. 2010. Perpajakan Indonesia. Jakarta: Indeks.

Waluyo. 2013. Perpajakan Indonesia. Edisi 11. Jakarta: Salemba Empat.

Zain, M. 2008. Manajemen Perpajakan. Edisi Ketiga. Jakarta: Salemba Empat. 